\title{
Investigation of chemical and microbiological properties of leblebi (roasted chickpeas) sold unpackaged in Çorum Province
}

\section{Çorum İlinde paketsiz satılan leblebilerin kimyasal ve mikrobiyolojik özelliklerinin incelenmesi}

\begin{abstract}
Gamze Nur MÜJDECi' ${ }^{1}$ (ID), Filiz KAYALAR ${ }^{1}$
\section{ABSTRACT}

Objective: Leblebi (roasted chickpea) is a traditional snack whose raw material is chickpeas. Commonly consumed in Turkey, and sold in sacks or containers without packages, it manifests diversely as yellow, white, chocolate, spicy and honey sesame. This study aimed to examine the chemical and microbiological properties of the leblebi varieties (yellow, chocolate and spicy) sold through traditional methods (unpackaged, bulk sale) in Turkey's Çorum province and examine the effects of open sales on these properties.

Methods: A total of 43 unpackaged leblebi samples, including spicy $(n=14)$, yellow $(n=16)$ and chocolate $(n=15)$ varieties were purchased from vendors in Çorum. One sample of yellow and chocolate leblebi was supplied from the factory. Moisture, ash, $\mathrm{NaCl}$, reducing and total sugar concentrations of the samples were determined according to AOAC, Mohr, DNS and phenol sulfuric acid methods, respectively. To determine the standard deviations of the chemical analysis results, SPSS software was used. The total yeast-mold (YM), mesophilic aerobic bacteria (TMAB), total Enterobacteriaceae (TE) and Staphylococcus aureus (SA) counts of samples were also determined using standards methods.
\end{abstract}

Results: The moisture, ash, glucose, and total sugar quantities of leblebi samples were found to be

\section{ÖZET}

Amaç: Leblebi, hammaddesi nohut olan geleneksel bir atıștırmalıktır. Türkiye'de yaygın olarak tüketilen ve ambalajsız çuval veya konteynırlarda satılan leblebi, sarı, beyaz, çikolatalı, baharatlı ve ballı-susamlı olarak çeșitli șekillerde tüketilmektedir. Bu çalıșmanın amacı, Türkiye'nin Çorum ilinde geleneksel yöntemlerle (ambalajsız, dökme) satılan leblebi çeșitlerinin (sarı, çikolatalı ve baharatı) kimyasal ve mikrobiyolojik özelliklerini belirlemek ve açık satışın leblebinin bu özellikleri üzerindeki etkilerini incelemektir.

Yöntem: Bu çalıșmada, baharatlı $(n=14)$, sarı $(n=16)$ ve çikolatalı $(n=15)$ olmak üzere toplam 43 adet ambalajsız leblebi numunesi Çorum'daki bayilerden satın alınmıștır. Birer adet sarı ve çikolatalı leblebi numunesi ise leblebi üretimi yapan bir fabrikadan temin edilmiștir. Örneklerin nem, kül, $\mathrm{NaCl}$, indirgen ve toplam șeker derișimleri sırasıyla; AOAC, Mohr, DNS ve fenol sülfürik asit yöntemlerine göre belirlenmiștir. Çalıșmada, kimyasal analiz sonuçlarının standart sapmalarını belirlemek için SPSS programı kullanılmıștır. Örneklerin toplam mayaküf (YM), mezofilik aerobik bakteri (TMAB), toplam Enterobacteriaceae (TE) ve Staphylococcus aureus (SA) sayıları da standart yöntemler kullanılarak belirlenmiștir.

Bulgular: Leblebi numunelerinin nem, kül, glukoz ve toplam șeker miktarlarının beklenen değer aralıklarında

${ }^{1}$ Hitit University, Faculty of Engineering, Department of Food Engineering, Çorum

İletişim / Corresponding Author : Gamze Nur MÜJDECi

Hitit Üniversitesi, Çevreyolu Bulvarı No: 819030 Çorum - Türkiye

E-posta / E-mail : gnurmujdecil@gmail.com

Geliş Tarihi/Received : 10.12 .2020 Kabul Tarihi / Accepted : 19.07.2021

DOI ID : 10.5505/TurkHijyen.2021.44342

Müjdeci GN, Kayalar F, Mehder G, Kılıç F. Investigation of chemical and microbiological properties of leblebi (roasted chickpeas) sold unpackaged in Çorum Province. Turk Hij Den Biyol Derg, 2021; 78(4): 535 - 544 
compatible with the expected value ranges and the results in the literature. Compared to the samples of yellow and chocolate leblebi taken from the factory, there was no significant increase in the number of total mesophilic aerobic bacteria (TMAB), yeast and mold (YM), Staphylococcus aureus (SA), and the total Enterobacteriaceae (TE) samples sold without packs and these were found to be below legal limits. However, the number of TMAB, YM, SA, and TE of some spicy samples was almost 0.5-5.0 log (CFU/g) higher compared to the sample taken directly from the factory.

Conclusion: In conclusion, contrary to what was expected in this study, the microbiological and chemical properties of the unpackaged leblebi samples were not deteriorated due to open sales and that they were within legal limits. However, the microbiological and chemical test results of some spiced leblebi samples were found to be above legal limits. We think this is due to cross contamination due to the seasoning process that takes place in the shop where it is sold.

Key Words: Chickpea, leblebi, unpacked, chemical property, microbiological property ve literatürdeki sonuçlarla uyumlu olduğu belirlenmiștir. Fabrikadan alınan sarı ve çikolatalı leblebi örnekleriyle karşılaștırıldığında, ambalajsız satılan leblebi örneklerindeki TMAB, YM, SA ve TE sayılarında önemli bir artıș olmadığı ve yasal limitlerin altında olduğu tespit edilmiștir. Ancak, bazı baharatlı örneklerin TMAB, YM, SA ve TE sayılarının, doğrudan fabrikadan alınan örneğe kıyasla neredeyse 0.5-5.0 log (kob/g) daha yüksek olduğu belirlenmiștir.

Sonuç: Sonuç olarak, bu çalıșmada beklenenin aksine ambalajsız olarak satılan leblebi numunelerinin mikrobiyolojik ve kimyasal özelliklerinin açık satıș nedeniyle bozulmadığı ve yasal sınırlar içinde olduğu belirlenmiștir. Ancak, bazı baharatı leblebi örneklerinin mikrobiyolojik ve kimyasal test sonuçları yasal sınırların üzerinde olduğu tespit edilmiștir. Bunun nedeninin; satıcıda gerçekleșen baharatlama sürecine bağlı olarak çapraz bulașmanın gerçekleșmesi olduğunu düșünmekteyiz.

Anahtar Kelimeler: Nohut, leblebi, ambalajsız, kimyasal özellik, mikrobiyolojik özellik

\section{INTRODUCTION}

Leblebi (roasted chickpeas) is a traditional snack of Turkey and is based on the pre-existence of about 1000 years. The raw material of leblebi is a chickpea that belongs to the Leguminosae family, Cicer genus, and C. arietinum L. species (1). According to the United Nations Food and Agriculture Organization data, most of the chickpeas are produced in Turkey, India, Russia, Kenya, Australia, Pakistan, Ethiopia, California, and Mexico (2). Chickpeas are used for many purposes in the food industry in Turkey and the most important of them is leblebi production (1). Approximately $20 \%$ of the chickpeas produced in Turkey are used as leblebi. Turkish leblebi is mostly exported to Spain, Tunisia, Greece, Germany, Italy, Israel, Syria, Lebanon, Jordan, and the United States (USA).
It is stated that chickpeas are rich in protein, carbohydrate, mineral, and vitamin content (1). According to published reports, the carbohydrate, protein, fat, and salt ratios (\%) in chickpeas are 60.70, 18.87, 8.61, and 0.15. Chickpeas strengthen the body, relieve brain and mental fatigue, increase appetite, strengthen the stomach and soften the intestines due to their nutritional richness.

It is also reported that this legume increases breast milk, increases sexual desire and strength, and relieves cough. However, chickpea is stated to be beneficial especially with its balancing effect on estrogen hormone during menopause (1).

In Turkey, the most consumed type of leblebi is "yellow leblebi". Yellow leblebi is produced in 
different ways, but the general production flow chart is given in Figure 1 (1).

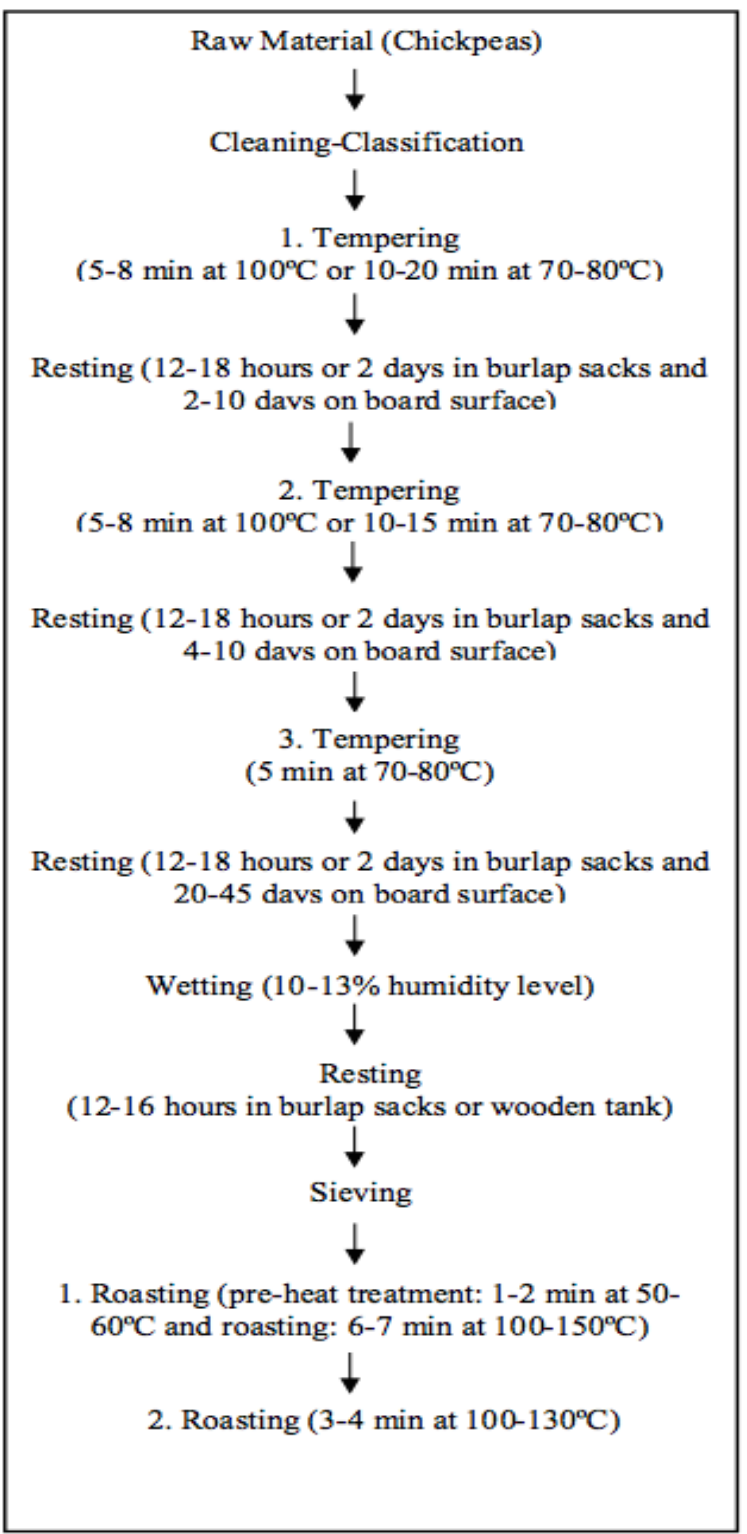

Figure 1. Yellow leblebi production flow chart

While traditionally open selling is more common in Turkey, Leblebi is also sold in sealed packaging in supermarkets. It is important to maintain the quality of food at every stage from production to the consumer's table. The most important factor that threatens human health in unpacked foods is that they are open to contamination due to the environment they are in. It is thought to be important to control the sale in the open, which sets the groundwork for food poisoning (3).

This study aimed to compare the microbiological and chemical properties of leblebi samples taken from a factory in Çorum and leblebi samples sold to the consumer in the open to determine the effects of open sales on the microbial quality of leblebi samples.

\section{MATERIAL and METHOD}

\section{Materials}

\section{Samples}

In the study, a total of 45 spicy (sample no. 1-14), yellow (sample no. 15-30), and chocolate leblebi (sample no. 30-45) samples were taken from a factory and local suppliers located in Çorum city in the period of August/2019 - May/2020. One yellow (sample no. 17) and one chocolate (sample no. 32) samples taken from the factory and after being taken into sterile bags they were brought to our laboratory under aseptic conditions. Unpackaged leblebi samples were weighed in bags of $250 \mathrm{~g}$ and brought to our laboratory after the package was captured.

\section{Methods}

\section{Chemical Analysis}

In the study, moisture, salt, ash, and sugar determinations of leblebi samples were carried out. Moisture and ash determination was carried out according to AOAC (4). Salt determination in leblebi samples was done according to the Mohr method, and reductive and total sugar determinations were made according to Dinitrosalicylic Acid (DNS) (5) and phenol sulfuric acid (6) methods, respectively. In this part of the study, all experiments were carried out in parallel.

Microbiological Analysis

Preparation of dilutions

Appropriate serial dilutions were prepared for microbiological analysis of chickpea samples in the study. $25 \mathrm{~g}$ of each leblebi sample was placed 
in a sterile stomacher bag and the sample was homogenized in $225 \mathrm{~mL}$ sterile $0.85 \%$ saline. For consecutive dilutions, $1 \mathrm{~mL}$ was taken from the previous dilution and added to $9 \mathrm{~mL}$ sterile saline.

Determination of total mesophilic aerobic bacteria count

In the study, Plate Count Agar (PCA) medium was used for mesophilic aerobic bacteria count. The medium was sterilized in an autoclave at $121^{\circ} \mathrm{C}$ for 15 minutes. After appropriate dilutions of leblebi samples were prepared, parallel inoculation was carried out by the surface spread method. Petri dishes were incubated at $30^{\circ} \mathrm{C}$ for 48 hours under aerobic conditions. Colonies that developed at the end of the incubation were counted as CFU (colony forming unit) per gram (7).

Determination of yeast and mold count

In the study, Potato Dextrose Agar (PDA) medium supplemented with $10 \%$ tartaric acid was used for the yeast-mold count. The medium was sterilized in an autoclave at $121^{\circ} \mathrm{C}$ for 15 minutes. After serial dilutions of leblebi samples were prepared, parallel cultivation was carried out by the surface spread method. Inoculated Petri dishes were incubated at $28^{\circ} \mathrm{C}$ for 48 hours under aerobic conditions. Colonies that developed at the end of the incubation were enumerated as CFU per gram (8).

\section{Determination of Staphylococcus aureus count}

At this stage of the study, parallel cultivation was carried out on the Baird Parker Agar medium supplemented with egg-yolk emulsion and potassium tellurite, which was sterilized at $121^{\circ} \mathrm{C}$ for 15 minutes, by spreading from the prepared dilutions to the surface. Petri dishes were incubated at $37^{\circ} \mathrm{C}$ for 24-48 hours under aerobic conditions. Typical black colonies that developed zone at the end of the incubation were counted as CFU per gram (9).

Determination of coliform group bacteria count

Violet Red Bile (VRB) Agar medium was used to count Enterobacteriaceae. The sterilized media in the water bath were inoculated by using the pour plate method, then the Petri dishes were incubated at $37^{\circ} \mathrm{C}$ for $18-24$ hours. Colonies developed at the end of the incubation were counted as CFU per gram. Bright pink-red colonies with a diameter of $0.5 \mathrm{~mm}$ or more were enumerated as coliform (10).

Statistical analysis

In the study, the SPSS software (SPSS 22.0) was used to determine the standard deviations of the chemical analysis results. The data were presented as mean $\pm \mathrm{SD}$.

\section{RESULTS}

The chemical analysis results of spicy leblebi samples are presented in Table 1 . When the results were examined, it was seen that the moisture contents (\%) in the samples were changed between $2.75 \pm 0.07$ and $6.15 \pm 0.07$. Ash contents (\%) of the samples were in the $2.45 \pm 0.07-6.05 \pm 0.35$ range. When the glucose concentrations in these samples were examined, it was determined that the glucose concentration (\%) of sample 12 was quite high $(2.91 \pm 0.85)$ compared to other samples. The glucose concentration (\%) in other spicy samples varied between $0.05 \pm 0.00$ and $0.79 \pm 0.00$. The total sugar concentration (\%) of the samples was determined in terms of sucrose and varied in the $1.34 \pm 0.00-10.20 \pm 0.00$ range. The highest total sugar concentration was determined in sample 10, and the lowest total sugar concentration was determined in sample 14 .

Moisture, ash, glucose, and total sugar concentration results of yellow leblebi samples are given in Table 2 . The highest moisture content $(4.15 \pm 0.07 \%)$ was determined in sample 16 , and the lowest moisture content $(1.15 \pm 0.07 \%)$ was determined in sample 19. Ash amounts (\%) in the samples were close to each other and varied between $1.80 \pm 0.08-2.79 \pm 0.01$. In yellow leblebi samples, glucose concentration (\%) changed in the $0.03 \pm 0.00-0.31 \pm 0.00$ range. The lowest glucose concentration was determined in sample 28 , while the highest glucose concentration was determined in sample 18. Besides, the total sugar concentrations (\%) of the samples were quite different from each other and changed in the $1.83 \pm 0.00-11.01 \pm 0.00$ range. The highest total sugar concentration was 
determined in sample 30, while the lowest total sugar concentration was determined in sample 24. Among the yellow leblebi samples, sample 17 was provided from the factory. Moisture and ash content (\%) in this example was determined as $2.55 \pm 0.35$ and $2.65 \pm 0.07$, respectively. The glucose and sucrose concentrations in sample no. 17 were determined as $0.07 \pm 0.00$ and $3.35 \pm 0.00$, respectively.

Table 1. Chemical analysis results of spicy leblebi samples (\%)

\begin{tabular}{|c|c|c|c|c|}
\hline Sample No & Moisture & Ash & Glucose & Total sugar \\
\hline 1 & $5.95 \pm 0.07$ & $2.75 \pm 0.07$ & $0.20 \pm 0.00$ & $4.45 \pm 0.00$ \\
\hline 2 & $4.25 \pm 0.07$ & $2.70 \pm 0.14$ & $0.20 \pm 0.00$ & $4.16 \pm 0.00$ \\
\hline 3 & $2.75 \pm 0.07$ & $3.88 \pm 0.00$ & $0.36 \pm 0.00$ & $3.49 \pm 0.00$ \\
\hline 4 & $3.60 \pm 0.00$ & $3.24 \pm 0.02$ & $0.79 \pm 0.00$ & $1.79 \pm 0.14$ \\
\hline 5 & $4.20 \pm 0.00$ & $4.04 \pm 0.14$ & $0.25 \pm 0.00$ & $5.40 \pm 0.00$ \\
\hline 6 & $5.75 \pm 0.07$ & $4.04 \pm 0.14$ & $0.25 \pm 0.00$ & $3.07 \pm 0.00$ \\
\hline 7 & $4.60 \pm 0.00$ & $2.80 \pm 0.57$ & $0.25 \pm 0.00$ & $5.60 \pm 0.00$ \\
\hline 8 & $5.00 \pm 0.00$ & $4.82 \pm 0.24$ & $0.44 \pm 0.00$ & $5.50 \pm 0.00$ \\
\hline 9 & $4.75 \pm 0.00$ & $3.72 \pm 0.14$ & $0.27 \pm 0.00$ & $5.10 \pm 0.00$ \\
\hline 10 & $4.15 \pm 0.00$ & $3.31 \pm 0.04$ & $0.15 \pm 0.00$ & $10.20 \pm 0.00$ \\
\hline 11 & $5.65 \pm 0.07$ & $2.45 \pm 0.07$ & $0.17 \pm 0.00$ & $9.16 \pm 0.21$ \\
\hline 12 & $5.10 \pm 0.00$ & $6.05 \pm 0.35$ & $2.91 \pm 0.85$ & $6.50 \pm 0.00$ \\
\hline 13 & $4.55 \pm 0.07$ & $5.17 \pm 0.10$ & $0.20 \pm 0.00$ & $2.40 \pm 0.00$ \\
\hline 14 & $6.15 \pm 0.07$ & $3.38 \pm 0.07$ & $0.05 \pm 0.00$ & $1.34 \pm 0.00$ \\
\hline
\end{tabular}

Table 2. Chemical analysis results of yellow leblebi samples (\%)

\begin{tabular}{|c|c|c|c|c|}
\hline Sample No & Moisture & Ash & Glucose & Total sugar \\
\hline 15 & $3.25 \pm 0.07$ & $2.75 \pm 0.07$ & $0.04 \pm 0.00$ & $8.14 \pm 0.00$ \\
\hline 16 & $4.15 \pm 0.07$ & $2.65 \pm 0.07$ & $0.19 \pm 0.00$ & $3.19 \pm 0.00$ \\
\hline 17 & $2.55 \pm 0.35$ & $2.65 \pm 0.07$ & $0.07 \pm 0.00$ & $3.35 \pm 0.00$ \\
\hline 18 & $3.10 \pm 0.07$ & $2.40 \pm 0.00$ & $0.31 \pm 0.00$ & $3.37 \pm 0.00$ \\
\hline 19 & $1.15 \pm 0.07$ & $2.70 \pm 0.04$ & $0.08 \pm 0.00$ & $5.94 \pm 0.00$ \\
\hline 20 & $3.00 \pm 0.00$ & $2.40 \pm 0.04$ & $0.20 \pm 0.00$ & $5.28 \pm 0.14$ \\
\hline 21 & $2.65 \pm 0.35$ & $1.80 \pm 0.08$ & $0.20 \pm 0.00$ & $2.30 \pm 0.00$ \\
\hline 22 & $2.75 \pm 0.00$ & $2.40 \pm 0.00$ & $0.20 \pm 0.00$ & $4.10 \pm 0.00$ \\
\hline 23 & $2.10 \pm 0.14$ & $2.79 \pm 0.01$ & $0.18 \pm 0.00$ & $4.80 \pm 0.00$ \\
\hline 24 & $2.12 \pm 0.00$ & $2.24 \pm 0.08$ & $0.18 \pm 0.00$ & $1.83 \pm 0.00$ \\
\hline 25 & $2.25 \pm 0.00$ & $2.52 \pm 0.01$ & $0.06 \pm 0.01$ & $5.50 \pm 0.00$ \\
\hline 26 & $2.72 \pm 0.35$ & $2.53 \pm 0.01$ & $0.06 \pm 0.00$ & $3.90 \pm 0.00$ \\
\hline 27 & $3.15 \pm 0.07$ & $2.35 \pm 0.07$ & $0.05 \pm 0.00$ & $2.25 \pm 0.00$ \\
\hline 28 & $4.00 \pm 0.00$ & $2.40 \pm 0.00$ & $0.03 \pm 0.00$ & $4.62 \pm 0.14$ \\
\hline 29 & $1.90 \pm 0.00$ & $2.04 \pm 0.45$ & $0.09 \pm 0.04$ & $3.90 \pm 0.00$ \\
\hline 30 & $3.05 \pm 0.00$ & $2.50 \pm 0.02$ & $0.14 \pm 0.00$ & $11.01 \pm 0.00$ \\
\hline
\end{tabular}


Chemical analysis results of chocolate leblebi samples are given in Table 3. The moisture amount (\%) of the chocolate leblebi samples was varied in the $1.10 \pm 0.00-2.50 \pm 0.00$ range, and the ash amount $(\%)$ of chocolate leblebi samples was in the $1.00 \pm 0.00$ $2.04 \pm 0.03$ range. The glucose and sucrose concentrations in chocolate leblebi samples were quite different from each other. The lowest glucose concentration was determined in sample 31 as $0.01 \pm 0.00 \%$ while the highest glucose concentration was determined in sample 45 as $0.62 \pm 0.00 \%$. The total sugar concentration in the chocolate leblebi samples was higher than other analyzed leblebi samples as expected. While the lowest total sugar concentration was determined in sample 35 as $3.60 \pm 2.83 \%$, the highest total sugar concentration $(43.35 \pm 0.00 \%)$ was determined in sample 42 . Among the samples of chocolate leblebi, sample 32 was provided from the factory. Moisture and ash content (\%) in this sample was determined as $1.90 \pm 0.14$ and $1.45 \pm 0.07$, respectively. Glucose and sucrose concentrations (\%) in sample 32 were determined as $0.70 \pm 0.00$ and $19.11 \pm 1.27$, respectively.

Table 3. Chemical analysis results of chocolate leblebi samples (\%)

\begin{tabular}{|c|c|c|c|c|}
\hline Sample No & Moisture & Ash & Glucose & Total sugar \\
\hline 31 & $2.00 \pm 0.00$ & $1.60 \pm 0.00$ & $0.01 \pm 0.00$ & $4.16 \pm 0.00$ \\
\hline 32 & $1.90 \pm 0.14$ & $1.45 \pm 0.07$ & $0.70 \pm 0.00$ & $19.11 \pm 1.27$ \\
\hline 33 & $1.95 \pm 0.07$ & $1.75 \pm 0.07$ & $0.70 \pm 0.00$ & $16.57 \pm 0.00$ \\
\hline 34 & $2.00 \pm 0.00$ & $1.68 \pm 0.06$ & $0.46 \pm 0.00$ & $8.53 \pm 0.00$ \\
\hline 35 & $1.50 \pm 0.00$ & $1.74 \pm 0.04$ & $0.23 \pm 0.00$ & $3.60 \pm 2.83$ \\
\hline 36 & $2.10 \pm 0.00$ & $1.70 \pm 0.00$ & $0.03 \pm 0.00$ & $22.34 \pm 0.00$ \\
\hline 37 & $1.90 \pm 0.00$ & $1.65 \pm 0.01$ & $0.73 \pm 0.00$ & $11.42 \pm 0.14$ \\
\hline 38 & $1.50 \pm 0.00$ & $1.40 \pm 0.00$ & $0.41 \pm 0.00$ & $10.30 \pm 0.00$ \\
\hline 39 & $2.50 \pm 0.00$ & $2.04 \pm 0.03$ & $0.03 \pm 0.00$ & $25.60 \pm 0.00$ \\
\hline 40 & $2.00 \pm 0.00$ & $1.46 \pm 0.05$ & $0.52 \pm 0.00$ & $9.80 \pm 1.41$ \\
\hline 41 & $2.10 \pm 0.00$ & $1.37 \pm 0.02$ & $0.43 \pm 0.00$ & $10.00 \pm 0.00$ \\
\hline 42 & $1.10 \pm 0.00$ & $1.00 \pm 0.00$ & $0.33 \pm 0.00$ & $43.35 \pm 0.00$ \\
\hline 43 & $2.35 \pm 0.21$ & $1.35 \pm 0.07$ & $0.41 \pm 0.00$ & $14.46 \pm 0.00$ \\
\hline 44 & $2.20 \pm 0.00$ & $1.57 \pm 0.04$ & $0.33 \pm 0.60$ & $31.70 \pm 0.00$ \\
\hline 45 & $2.15 \pm 0.00$ & $1.30 \pm 0.14$ & $0.62 \pm 0.00$ & $13.95 \pm 0.00$ \\
\hline
\end{tabular}

Microbiological analysis results of spicy leblebi samples are given in Table 4. The total number of total mesophilic aerobic bacteria (TMAB) in these samples varied from 4.10 to $7.72 \log$ (CFU/g). The number of yeast-mold $(Y M)$ in these samples ranged between 2.74-5.73 log (CFU/g), while the number of $S$. aureus (SA) varied from 2.34 to $4.45 \log$ (CFU/g). It was observed that the number of coliform bacteria (CB) in some spicy leblebi samples was below the detection limits $(<10)$ and while the rest was in the 1.90-5.45 log $(\mathrm{CFU} / \mathrm{g})$ range. The number of TMAB in yellow leblebi samples ranged from 2.00 to $6.34 \log (\mathrm{CFU} / \mathrm{g})$. The number of YM, SA, and CB in some yellow leblebi samples was below the dtection limits. Besides, the number of $Y M, S A$, and $C B$ in the remaining samples ranged from 2.48-3.49, 1.00-4.34, and 1.30-6.96 (CFU/g), respectively (Table 5). In chocolate leblebi samples, the number of TMAB in 2 of 15 samples was below the detection limits $(<100)$. It was determined that the number of TMAB in the remaining samples ranged from 2.30 to 7.62 (CFU/g). While the number of YM, SA, and CB in most chocolate leblebi samples were 
below the detection limits, the highest number of YM sample 32 and the highest number of CB (3.04 (CFU/g)) (3.48 (CFU/g)) and SA (3.23 (CFU/g)) were obtained in was in sample 39 (Table 6).

Table 4. Microbiological analysis results of spicy leblebi samples (CFU/g)

\begin{tabular}{|c|c|c|c|c|}
\hline Sample No & TMAB & YM & SA & $<1.00$ \\
\hline 1 & 5.70 & 4.06 & 4.20 & 1.90 \\
\hline 2 & 5.78 & 4.07 & 3.05 & 3.41 \\
\hline 3 & 4.30 & 2.78 & 2.88 & 3.18 \\
\hline 4 & 5.34 & 3.64 & 4.15 & $<1.00$ \\
\hline 5 & 5.07 & 3.81 & 3.97 & 3.53 \\
\hline 6 & 7.11 & 5.33 & 2.35 & $<1.00$ \\
\hline 7 & 6.48 & 4.48 & 3.60 & 3.46 \\
\hline 8 & 4.90 & 4.21 & 4.45 & 5.45 \\
\hline 9 & 7.48 & 3.72 & 2.34 & 2.59 \\
\hline 10 & 7.72 & 4.48 & 3.18 & $<1.00$ \\
\hline 11 & 4.72 & 3.02 & 3.88 & $<1.00$ \\
\hline 13 & 5.26 & 2.74 & 4.45 & 3.32 \\
\hline
\end{tabular}

TMAB: Total mesophilic aerobic bacteria, YM: Yeast-Mold, SA: S. aureus, CB: Coliform bacteria

Table 5. Microbiological analysis results of yellow leblebi samples (CFU/g)

\begin{tabular}{|c|c|c|c|c|}
\hline Sample No & TMAB & YM & SA & $<1.00$ \\
\hline 15 & 2.74 & $<2.00$ & 2.30 & 1.00 \\
\hline 16 & 4.26 & 2.60 & 3.04 & $<1.00$ \\
\hline 17 & 5.30 & 2.88 & $<1.00$ & $<.30$ \\
\hline 18 & 2.00 & 3.41 & $<1.00$ & $<1.00$ \\
\hline 19 & 2.30 & $<2.00$ & $<1.00$ & 1.00 \\
\hline 20 & 4.04 & $<2.00$ & $<1.00$ & 2.15 \\
\hline 21 & 6.34 & $<2.00$ & $<1.00$ & 3.40 \\
\hline 22 & 4.00 & $<2.00$ & 4.34 & $<1.00$ \\
\hline 23 & 2.00 & $<2.00$ & 1.30 & 2.75 \\
\hline 24 & 3.38 & $<2.00$ & 1.48 & 1.90 \\
\hline 25 & 4.74 & 2.48 & $<1.00$ & 2.80 \\
\hline 26 & 4.26 & 3.49 & 1.90 & $<1.00$ \\
\hline 27 & 3.90 & $<2.00$ & 1.00 & 6.96 \\
\hline 28 & 2.48 & $<2.00$ & $<1.00$ & 2.20 \\
\hline 29 & 3.30 & $<2.00$ & $<1.00$ & \\
\hline 30 & 5.45 & 3.36 & & \\
\hline
\end{tabular}

TMAB: Total mesophilic aerobic bacteria, YM: Yeast-Mold, SA: S. aureus, CB: Coliform bacteria 
Table 6. Microbiological analysis results of yellow leblebi samples (CFU/g)

\begin{tabular}{|c|c|c|c|c|}
\hline Sample No & TMAB & YM & SA & $<1.00$ \\
\hline 31 & 2.30 & $<2.00$ & 3.23 & $<1.00$ \\
\hline 32 & 4.30 & 3.48 & $<1.00$ & 1.60 \\
\hline 33 & $<2.00$ & 2.78 & $<1.00$ & 2.85 \\
\hline 34 & 2.78 & $<2.00$ & $<1.00$ & $<1.00$ \\
\hline 35 & 3.72 & 2.30 & $<1.00$ & $<1.00$ \\
\hline 36 & 4.46 & $<2.00$ & $<1.00$ & $<1.00$ \\
\hline 37 & 5.18 & $<2.00$ & $<1.00$ & $<1.00$ \\
\hline 38 & 5.90 & $<2.00$ & 2.00 & 3.04 \\
\hline 39 & 3.10 & $<2.00$ & 2.00 & 2.57 \\
\hline 40 & 4.84 & 2.30 & $<1.00$ & 2.11 \\
\hline 41 & 4.60 & $<2.00$ & 1.30 & $<1.00$ \\
\hline 42 & $<2.00$ & $<2.00$ & 3.08 & 2.65 \\
\hline 43 & 4.10 & 2.30 & $<1.00$ & 2.26 \\
\hline 44 & 7.62 & $<2.00$ & $<1.00$ & 2.38 \\
\hline 45 & 4.86 & $<2.00$ & \\
\hline
\end{tabular}

TMAB: Total mesophilic aerobic bacteria, YM: Yeast-Mold, SA: S. aureus, CB: Coliform bacteria

\section{DISCUSSION and CONCLUSION}

Roasting processes in leblebi production (see Figure 1) decrease the amount of moisture in chickpeas, so the amount of moisture in leblebi is quite low compared to raw chickpeas. Low moisture content extends the shelf life of leblebi. The moisture content of the yellow and chocolate leblebi samples examined in this study was as low as it should be. However, the amount of moisture in some spicy leblebi samples was slightly higher than the others. The reason for this is that the seasoning step may slightly increase the amount of moisture. It was seen that the amounts of ash in yellow and chocolate leblebi samples tested in this study were close to that of raw chickpeas. In spicy leblebi samples, the amount of ash increased as expected, due to the added seasoning powder. While the glucose concentration in leblebi samples was determined within the range similar to that of raw chickpeas, the total sugar concentration in chocolate leblebi was higher depending on the added sucrose.
Researches showed that the amount of moisture and ash in the raw chickpea (\%) ranged between 7.710.8 and 2.43-3.53, glucose concentration (\%) 0.1-0.7, and total sugar concentration in the range of 3.10 15.2 (11-18). In a study conducted by Özbey (17), the moisture, ash, and total carbohydrate amounts (\%) in yellow leblebi were reported to be $3.31,2.49$, and 62.13 , respectively. Another study reported that the amount of ash in yellow leblebi ranged from 2.52 to $2.80 \%$ (18). Simsek et al. (15) reported that moisture and ash content $(\mathrm{g} / \mathrm{kg})$ of a yellow leblebi sample was 31.76 and 29.71, respectively. In another study conducted by Özbey and Görgülü (16), it was stated that the moisture content (\%) of a total of 45 yellow roasted chickpea samples varied between 0.89 and 7.53 and the amount of ash (\%) varied between 2.30 and 5.92. In a review, it was emphasized that the average amounts of moisture and ash in yellow leblebi (\%) were 6.42 and 2.80, respectively, while dextrin and sugar concentrations (\%) were 1.48 and 1.97 , respectively (11). It is seen that the results 
of moisture and ash analysis in this study are quite compatible with the results obtained in the literature

As far as we know, there is no study in the literature in which microbiological characterization of leblebi is performed. According to the Microbiological Criteria Announcement of Turkish Food Codex, the maximum number of TMAB and YM in nuts including leblebi must be 5 and 4 logs (CFU/g), respectively. International Commission on Microbiological Specifications for Foods (ICMSF) suggests testing Enterobacteriaceae in dried legumes as an indication of either postprocessing contamination or inadequate hygiene (19). According to NSW Authority, Enterobacteriaceae numbers must be less than 4 log (CFU/g) in ready-toeat foods including dried legumes (20).

Our results showed that the number of TMAB in almost all of the spicy leblebi samples sold unpackaged was above the legal limits. It was determined that in five of the 14 spiced chickpea samples, YM numbers were above the legal limit. The number of CB in only one of the samples was above the acceptable limit. In the production of spicy leblebi, yellow leblebi obtained from the factory are brought to the dealer, and spice mix is added during the final roasting process that takes place in the shop. This last process in the shop, microbial contamination from spices, and unpackaged sale may be increased the number of TMAB, YM, SA, and CB in almost all spicy samples compared to the sample taken from the factory (sample no. 17). When the microbiological analysis results of the unpackaged yellow leblebi samples were examined, it was found that the number of $T M A B$ in only two of these samples and the number of $C B$ in one of them were above the legal limits.

In this study, it was determined that the number of TMAB, YM, and CB in the chocolate leblebi sample (sample no. 32) taken from the factory was complied with the legal limits. Three of the 15 samples in total did not meet legal limits in terms of the number of TMAB. The numbers of $Y M$ and $C B$ in all of the chocolate leblebi samples studied were below the recommended limits.

The water activity of chickpeas is generally below 0.65 , and only some xerophilic fungi and yeasts can grow. The presence of $S$. aureus in the leblebi may be associated with cross-contamination. This cross-contamination usually occurs in foods sold unpackaged, by customers or employees handling products without taking any precautions, such as wearing gloves. Analysis results in this study showed that open selling did not increase the SA number of yellow and chocolate leblebi samples compared to factory samples. But, the number of SA in spicy leblebi samples has increased. We believe this was caused by cross-contamination from staff during the seasoning process that took place in the shop.

In this study, the effects of unpacked sales on the chemical and microbiological properties of leblebi samples were investigated. The research was initiated by expecting that the amount of moisture and microbial load in leblebi samples sold in open would be higher than leblebi samples obtained from the factory. However, the research results showed that the sale of leblebi (yellow and chocolate) in the open did not affect its chemical and microbiological properties. These results showed that the conditions of sale of leblebi were hygienic and virtually risk-free microbiologically. However, the seasoning stage of the spicy leblebi increased the microbial load due to cross-contamination in the shop. For this reason, it is recommended that microbial control of leblebi be carried out frequently in terms of public health. 


\section{ACKNOWLEDGMENT}

The authors would like to express their thanks to The Scientific and Technological Research Council of Turkey (Project no: 1919B011900802) for the financial support of this study.

\section{ETHICS COMITTEE APPROVAL}

* This study does not require Ethics Committee Approval.

\section{CONFLICT OF INTEREST}

The authors declare no conflict of interest.

\section{REFERENCES}

1. Gürsul I, Batu A. Geleneksel Ve Modern Yönteme Göre Ağın Leblebisi Üretimi. Gıda Teknol Elektro Derg, 2010; 5 (1): 57-65.

2. www.fao.org, Erișim tarihi: 10.02.2019.

3. Sertaç A, Kapusuz F. Açıkta Satılan Gıdalar: Öğrencilerin görüșleri ve tercih etme nedenleri üzerine bir araștırma. Gıda Teknol Elektro Derg, 2010; 5 (3): 25-35.

4. AOAC. Official methods of analysis of AOAC international. Maryland, 1997.

5. Miller GL. Use of Dinitrosalicylic Acid Reagent for Determination of Reducing Sugar. Anal Chem, 1959; 31 (3): 426-8.

6. Dubois M, Gilles KA, Hamilton JK, Rebers PA, Smith F. Colorimetric Method for Determination of Sugars and Related Substances. Anal Chem, 1956; 28 (3):350.

7. Carrizosa E, Benito MJ, Ruiz-Moyano S, Hernández A, Villalobos M del C, Martín A. Bacterial communities of fresh goat meat packaged in modified atmosphere. Food Microbiol, 2017; 65: 57-63.

8. Çelikel GA, Gürbüz S, Akın M, Palabiçak B. Mardin İlinde Satıșa Sunulan Endüstriyel ve Geleneksel Yöntemle Üretilen Yoğurtların Kalite Kriterlerinin Araștırılması. ADÜ Ziraat Derg, 2020; 17 (2): 221-6.

9. Koçyiğit A, Karaboz I, İzmir'de Çeșitli Marketlerde Satışa Sunulan Tavuk ve Hindi Etlerinde Staphylococcus aureus Aranması, Sayımı ve Tanımlanması. Gıda, 2005; 30 (4): 281-5.

10. Çitak S, Gündoğan N, Kala E. Evaluation of Coliform and Enterococcus as Fecal Indicator Bacteria in Frozen Meat and Vegetables in Ankara. Türk Hij Den Biy Derg, 2009; 39 (4): 145-51.

11. Coșkuner $Y$, Karababa E. Leblebi: A roasted chickpea product as a traditional turkish snack food. Food Rev Int, 2004; 20 (3): 257-74.
12. Daur I, Khan IA, Jahangir M. Nutritional Quality of Raw and Soaking Compared To Pressure-Cooked (Cicer arietinum L.) Seeds. World J Pharm Pharm Sci, 2015; 4 (5): 669-83.

13. Jukanti AK, Gaur PM, Gowda CLL, Chibbar RN. Nutritional quality and health benefits of chickpea (Cicer arietinum L.): A review. Br J Nutr, 2012; 108 (1), 11-26.

14. Rachwa-Rosiak D, Nebesny E, Budryn G. ChickpeasComposition, Nutritional Value, Health Benefits, Application to Bread and Snacks: A Review. Crit Rev Food Sci Nutr, 2015; 55 (8): 1137-45.

15. Simsek S, Herken EN, Ovando-Martinez M. Chemical composition, nutritional value and in vitro starch digestibility of roasted chickpeas. J Sci Food Agric, 2016; 96 (8): 2896-905.

16. Özbey $F$, Görgülü M. Survey of trace element and dietetic fiber composition of "Leblebi" which is a local snack food consumed in Turkey. Food Sci Technol, 2016; 36 (2): 351-5.

17. Özbey F. Effect of traditional processing steps on chemical and nutritional composition of leblebi. Acta Aliment, 2017; 46 (3): 290-6.

18. Sağlam H, Aseydim AC. Leblebi Üretiminde İkinci Kavurma Koșullarının Leblebi'nin Fizikokimyasal Özellikleri ve Duyusal Kalitesi Üzerine Etkisi. Harran Tarım ve Gıda Bilim Derg, 2017; 21(3): 279-92.

19. Swanson KM. Microorganisms in Foods 8. 1. edition. Boston; Springer, 2011.

20. New South Wales (NSW Food Authority). Microbiological quality guide for ready to-eat foods. A guide to interpreting microbiological results. NSW Food Auth, 2009; (July): 9. 